\title{
RINGKASAN TEORI EROSI DAN SEDIMENTASI
}

\author{
Asriadi Asriadi ${ }^{1}$, Hendrik Pristianto ${ }^{2)}$ \\ ${ }^{1), 2)}$ Program Studi Teknik Sipil Universitas Muhammadiyah Sorong \\ J1 Pendidikan No 27 Kota Sorong, Email : asriadisoq89@gmail.com
}

\section{A. Erosi}

\section{Erosi dan proses terjadinya}

Erosi merupakan peristiwa berpindahnya tanah atau bagian-bagian tanah dari suatu tempat ke tempat lain oleh media alam, seperti: angin dan air. Pada daerah beriklim tropika basah seperti di Indonesia proses erosi umumnya disebabkan oleh air, sedangkan pada daerah yang beriklim kering penyebab utama terjadinya erosi adalah angin (Arsyad, 2006).

Proses terjadinya erosi ditentukan oleh faktor-faktor hidrologi terutama intensitas hujan, topografi, karakteristik tanah, vegetasi penutup lahan, dan tata guna lahan.

Sejarah erosi berhubungan dengan terjadinya alam dan keberadaan manusia dimuka bumi ini. Erosi alam terjadi melalui pembentukan tanah untuk mempertahankan keseimbangan tanah secara alamiah. Erosi karena kegiatan manusia disebabkan oleh terkelupasnya lapisan tanah bagian atas akibat cara bercocok tanam yang tidak mengindahkan kaidah-kaidah konservasi tanah atau kegiatan pembangunan konstruksi yang bersifat merusak keadaan fisik tanah.

Menurut proses kejadiannya, maka erosi dibedakan kedalam:

a. Erosi geologi

Erosi geologi terjadi sejak permukaan bumi terbentuk yang menyebabkan terkikisnya batuan sehingga terjadilah bentuk morfologi permukaan bumi seperti yang terdapat sekarang ini.

b. Erosi normal

Erosi normal atau erosi alami merupakan proses pengangkutan tanah atau bagian-bagian tanah yang terjadi dibawah keadaan alami. Proses erosi alam terjadi dengan laju yang lambat, sehingga memungkinkan terbentuknya lapisan tanah yang tebal yang mampu mendukung pertumbuhan vegetasi secara normal.

c. Erosi dipercepat

Erosi dipercepat atau erosi karena yang disebabkan oleh campur tangan manusia merupakan proses pengangkutan tanah dengan laju yang jauh lebih cepat dari pembentukan tanah yang dapat menimbulkan kerusakan tanah akibat perbuatan manusia dalam mengelola sumber daya alam.

Sedangakan menurut bentuknya, erosi terdiri dari:

(a) Erosi percikan

Erosi percikan merupakan hasil erosi yang disebabkan oleh energi kinetik air hujan yang menyebabkan terkelupasnya partikel-partikel tanah bagian atas.

(b) Erosi lembar

Erosi lembar atau biasa juga disebut erosi kulit merupakan proses pengangkutan lapisan tanah yang merata tebalnya dari suatu permukaan tanah. Erosi lembar terjadi ketika lapisan tipis permukaan tanah didaerah berlereng terkikis oleh lapisan kombinasi air hujan dan air larian (run off). Tipe erosi ini disebabkan oleh kombinasi air hujan dan air larian yang mengalir ketempat yang lebih rendah.

(c) Erosi alur

Erosi alur adalah proses terangkutnya tanah dari alur-alur tertentu pada permukaan tanah. Erosi alur terjadi oleh aliran air larian sehingga menyebabkan pengelupasan yang diikuti dengan pengangkutan partikel-partikel tanah kemudian terkonsentrasi didalam saluransaluran air. Hal ini terjadi ketika air larian masuk kedalam cekungan permukaan tanah, kecepatan air larian meningkat, dan akhirnya terjadilah angkutan sedimen. 
(d) Erosi parit

Proses terjadinya erosi parit sama dengan erosi alur, akan tetapi alur yang terbentuk sedemikian besarnya sehingga tidak dapat lagi dihilangkan dengan pengolahan tanah biasa. Hasil erosi parit membentuk jajaran parit yang lebih dalam dan lebar dan merupakan tingkat lanjutan dari erosi alur. Erosi parit dapat diklasifikasikan sebagai parit bersambungan dan parit terputus-putus.

(e) Erosi tebing sungai

Erosi tebing sungai adalah proses terkikisnya tanah pada tebing-tebing sungai dan penggerusan dasar sungai oleh aliran air sungai. Erosi tebing sungai terjadi sebagai akibat pengikisan tebing sungai oleh air yang mengalir dari bagian atas tebing atau oleh terjangan aliran sungai yang kuat pada belokan sungai. Dua proses berlangsungnya erosi tebing sungai disebabkan oleh adanya gerusan aliran sungai dan oleh adanya longsoran tanah pada tebing sungai.

(f) Longsoran

Longsor merupakan suatu bentuk erosi yang proses pemindahan tanahnya terjadi pada saat bersamaan dalam volume besar dan sekaligus. Longsor terjadi sebagai akibat meluncurnya suatu volume tanah dalam volume besar diatas suatu lapisan yang agak kedap sampai jenuh air. Proses terjadinya longsoran terjadi apabila:

1) Lereng yang cukup curam, sehingga volume tanah dapat bergerak atau meluncur kebawah

2) Terdapat lapisan dibawah permukaan tanah yang kedap air dan lunak yang akan menjadi bidang luncur

3) Terdapat cukup air dalam tanah, sehingga lapisan tanah tepat diatas lapisan kedap air yang menjadi jenuh

\section{Faktor-faktor yang mempengaruhi erosi}

Di daerah berikilim tropika basah, faktor air merupakan penyebab utama terjadinya erosi tanah, sedangkan faktor angin dan salju tidak terlalu signifikan. Beberapa faktor yang mempengaruhi terjadinya erosi, meliputi:

(a) Iklim

Pengaruh iklim terhadap erosi bersifat lansung melalui tenaga kinetis air hujan, terutama intensitas dan diameter butiran air hujan. Pada hujan yang intensif dan berlangsung dalam waktu pendek, erosi yang terjadi biasanya lebih besar daripada hujan dengan intensitas lebih kecil dengan waktu hujan lebih lama.

Besarnya curah hujan, intensitas, dan distribusi hujan menentukan kekuatan dispersi hujan terhadap tanah, jumlah dan kekuatan aliran permukaan serta tingkat kerusakan erosi yang ditimbulkan.

Besarnya curah hujan adalah volume air yang jatuh pada suatu areal tertentu. Besarnya curah hujan dinyatakan dalam $\mathrm{m}^{3}$ per satuan luas atau dalam $\mathrm{mm}$. Besarnya curah hujan dapat dinyatakan untuk satu kali hujan atau masa tertentu dalam per hari, per bulan, per musim, dan per tahun. Sedangkan intensitas hujan menyatakan besarnya hujan yang jatuh dalam suatu waktu yang singkat, yakni: $5,10,15$, atau 30 menit yang dinyatakan dalam $\mathrm{mm} / \mathrm{jam}$ atau $\mathrm{cm} / \mathrm{jam}$.

Beberapa persamaan intensitas hujan yang telah dikembangkan oleh para ahli dan sering digunakan, tergantung pada ketersediaan data dan jenis alat pengukur curah hujan.

Perhitungan $\mathrm{EI}_{30}$ dihitung untuk setiap kejadian hujan dengan menggunakan persamaan:

dimana:

$$
\mathrm{EI}_{30}=\sum \mathrm{E}\left(\mathrm{I}_{30} \cdot 10^{-2}\right)
$$

$\mathrm{E}=$ Energi kinetik suatu hujan (ton.meter $/ \mathrm{ha} / \mathrm{cm}$ )

$\mathrm{I}_{30}=$ Intensitas hujan maksimum yang terjadi selama 30 menit $(\mathrm{cm} / \mathrm{jam})$ 
$\mathrm{EI}_{30}=$ Hubungan interaksi antara energi kinetik hujan dengan intensitas hujan maksimum selama 30 menit

Sedangkan untuk menghitung besarnya energi kinetik hujan (E) digunakan persamaan Wischmeier dan Smith, 1978:

$$
\mathrm{E}=210+89 \log \mathrm{i}
$$

dimana:

$\mathrm{E}=$ Energi kinetik hujan selama periode hujan (ton.m/ha/cm)

$\mathrm{I}_{30}=$ Intensitas hujan maksimum selama 30 menit $(\mathrm{cm} / \mathrm{jam})$.

$\mathrm{EI}_{30}$ merupakan indeks potensial erosi hujan atau selanjutnya disebut indeks erosi hujan.

Metode lain untuk menghitung besarnya $\mathrm{EI}_{30}$ menggunakan persamaan Lenvain, (1975 dalam Bols, 1978), yakni hubungan antara $\mathrm{EI}_{30}$ dengan curah hujan tahunan rata-rata $(\mathrm{R})$ :

$$
\mathrm{EI}_{30}=2,34 \mathrm{R}^{1,98}
$$

Sedangkan persamaan $\mathrm{EI}_{30}$ yang dikembangkan oleh Bols (1978), yang merupakan kerjasama teknik Balai Penelitian Tanah Bogor dengan Pemerintah Belgia:

$$
\mathrm{EI}_{30}=6,119(\mathrm{RAIN})^{1,21}(\mathrm{DAYS})^{-0,47}(\mathrm{MAXP})^{0,53}
$$

dimana:

$\mathrm{EI}_{30} \quad=$ Indeks erosi hujan bulanan

RAIN = Curah hujan rata-rata bulanan $(\mathrm{cm})$

DAYS = Jumlah hari hujan rata-rata per bulan

MAXP = Curah hujan maksimum dalam satu bulan $(\mathrm{cm})$.

Dalam memperkirakan besarnya erosi dengan menggunakan persamaan USLE, maka untuk variabel hujan yang digunakan adalah nilai rata-rata $\mathrm{EI}_{30}$ tahunan yang dihasilkan dari penjumlahan sejumlah $\mathrm{EI}_{30}$ bulanan. Indeks erosi hujan adalah kemampuan suatu hujan untuk menimbulkan erosi atau dalam analisis USLE disebut erosivitas hujan.

(b) Sifat-sifat tanah

Sifat-sifat tanah yang menentukan dalam erodibilitas tanah yaitu:

1) Tekstur tanah, biasanya berkaitan dengan ukuran dan porsi partikel-partikel tanah dan akan membentuk tipe tanah tertentu.

2) Unsur organik, terdiri atas limbah tanaman dan hewan sebagai hasil proses dekomposisi. Unsur organik cenderung memperbaiki struktur tanah dan bersifat meningkatkan permeabilitas tanah, kapasitas tampung air tanah, dan kesuburan tanah.

3) Struktur tanah, adalah susunan partikel-partikel tanah yang membentuk agregat. Struktur tanah mempengaruhi kemampuan tanah dalam menyerap air tanah. Struktur tanah granular dan lepas mempunyai kemampuan besar dalam meloloskan air larian sehingga menurunkan laju air larian dan memacu pertumbuhan tanaman.

4) Permeabilitas tanah, menunjukkan kemampuan tanah dalam meloloskan air. Tanah dengan permeabilitas tinggi menaikkan laju infiltrasi sehingga menurunkan laju air larian.

(c) Topografi

Kemiringan dan panjang lereng merupakan dua variabel topografi yang paling berpengaruh dalam analisis erosi dan aliran permukaan. Kedua faktor tersebut penting untuk terjadinya erosi karena faktor-faktor tersebut menentukan besarnya kecepatan dan volume air larian. Kecepatan air larian ditentukan oleh kemiringan lereng dan panjang kelerengan yang terkonsentrasi pada saluran-saluran sempit yang mempunyai potensi besar untuk terjadinya erosi alur maupun erosi parit.

(d) Vegetasi penutup lahan.

Pengaruh vegetasi penutup tanah terhadap erosi adalah:

1) Melindungi permukaan tanah dari tumbukan air hujan (menurunkan kecepatan terminal dan memperkecil diameter air hujan)

2) Menurunkan kecepatan dan volume air larian 
3) Menahan partikel-partikel tanah pada tempatnya melalui sitem perakaran dan seresah yang dihasilkan

4) Mempertahankan kemantapan kapasitas tanah dalam menyerap air.

\section{Perkiraan besarnya erosi}

Untuk memperkirakan besarnya erosi yang terjadi ditentukan oleh intensitas hujan dan bentuk aktifitas pengelolaan lahan oleh manusia, disamping faktor topografi dan sifat tanah. Perkiraan besarnya erosi pada suatu lahan dapat digunakan untuk perencanaan peggunaan lahan dan tindakan konservasi tanah yang tepat, agar tidak terjadi kerusakan tanah sehingga tanah tersebut dapat digunakan secara produktif dan berkesinambungan. Perkiraan erosi juga digunakan untuk menilai apakah suatu program tindakan konservasi tanah telah berhasil mengurangi erosi dari suatu DAS. Cara perkiraan erosi merupakan alat bantu untuk mengetahui besarnya erosi yang akan terjadi sehingga pengambilan keputusan bisa secara tepat dalam perencanaan konservasi tanah pada suatu penggunaan lahan.

Dari beberapa metode yang ada untuk memperkirakan besarnya erosi permukaan, maka metode USLE yang dikembangkan oleh Wischmeier dan Smith (1978) dalam Arsyad (2006) adalah metode yang paling umum digunakan. Cara memperkirakan besarnya erosi lainnya adalah dengan menggunakan data muatan sedimen, berat jenis tanah, dan besarnya nisbah pelepasan sedimen (sediment delivery ratio), yang akan dibahas lebih lanjut.

a. Metode USLE atau modifikasi USLE

Persamaan matematis USLE yang dikembangkan oleh Wischmeier dan Smith (1978) dalam Arsyad (2006):

$$
\mathrm{A}=\mathrm{R} \text { K LS C P }
$$

dimana:

$$
\begin{aligned}
& \mathrm{A}=\text { Banyaknya tanah tererosi (ton/ha/tahun) } \\
& \mathrm{R}=\text { Faktor curah hujan/erosivitas curah hujan } \\
& \mathrm{K}=\text { Faktor erodibilitas tanah } \\
& \mathrm{LS}=\text { Faktor panjang dan kemiringan lereng } \\
& \mathrm{C}=\text { Faktor vegetasi penutup tanah dan pengelolaan tanaman } \\
& \mathrm{P} \quad=\text { Faktor tindakan-tindakan khusus konservasi tanah }
\end{aligned}
$$

Besarnya erosi diperoleh dari perkalian faktor-faktor yang berkaitan dengan curah hujan, jenis tanah, panjang dan kemiringan lereng, sistem tanam, dan tindakan konservasi tanah dan air.

1) Faktor curah hujan $(\mathrm{R})$

Faktor curah hujan (R) merupakan daya rusak air hujan yang menyebabkan terkelupas dan terangkutnya partikel-partikel tanah ke tempat yang lebih rendah. Nilai $\mathrm{R}$ atau erosivitas hujan tahunan dapat dihitung dari data curah hujan yang didapat dari stasiun penakar curah hujan otomatis dengan menggunakan persamaan (1) dan (2). Jika tidak terdapat data hujan yang dapat digunakan dalam persamaan (1) dan (2), maka besarnya $\mathrm{R}$ dapat dihitung dari data hujan biasa menggunakan persamaan (3) dan (4).

2) Faktor erodibilitas tanah (K)

Faktor erodibilitas tanah $(\mathrm{K})$ menunjukkan resistensi tanah terhadap pengelupasan dan transportasi partikel-partikel tanah oleh adanya energi kinetik air hujan. Meskipun besarnya resistensi tersebut diatas tergantung pada topografi, kemiringan lereng, dan besarnya gangguan oleh manusia, resistensi tanah juga ditentukan oleh karakteristik tanah seperti tekstur tanah, stabilitas agregat tanah, kapasitas infiltrasi, dan kandungan organik dan kimia tanah. Karakteristik tanah tersebut bersifat dinamis dan selalu berubah. Karakteristik tanah dapat berubah seiring dengan perubahan waktu dan tataguna lahan. Perubahan erodibilitas tanah berlangsung ketika terjadi hujan karena pada waktu tersebut partikel-partikel tanah mengalami perubahan orientasi dan karakteristik bahan kimia dan fisika tanah. 
Peranan tekstur tanah terhadap besar kecilnya erodibiltas tanah adalah besar. Tanah dengan partikel agregat kasar, resistensinya terhadap daya angkut air larian besar karena diperlukan energi yang cukup besar untuk mengangkut partikel-partikel tanah tersebut. Sebaliknya tanah dengan partikel agregat halus, daya tahan terhadap pengelupasan kecil karena sifat kohesi tanah tersebut juga kecil. Partikel debu dan pasir halus kurang resisten dibandingkan agregat kasar, dengan demikian kandungan debu tinggi mempunyai sifat erodibilitas besar.

Wischmeier et al., (1971) dalam Asdak (2004), mengembangkan persamaan matematis yang menghubungkan karakteristik tanah dengan tingkat erodibilitas tanah sebagai berikut :

$$
\begin{aligned}
& \mathrm{K}=\left\{2,71 \times 10^{-4}(12-\mathrm{OM}) \mathrm{M}^{1,14}+3,25(\mathrm{~S}-2)+2,5(\mathrm{P}-3) / 100\right\} \\
& \mathrm{K}=\text { Erodibilitas tanah } \\
& \mathrm{OM}=\% \text { unsur organik } \\
& \mathrm{S}=\text { Kode klasifikasi struktur tanah } \\
& \mathrm{P}=\text { Permeabilitas tanah } \\
& \mathrm{M}=\% \text { ukuran partikel }(\% \text { debu+pasir sangat halus }) \times(100-\% \text { liat })
\end{aligned}
$$

Nilai M untuk beberapa klas tekstur tanah yang telah ditentukan dapat dilihat pada tabel 1 . Sedangkan besarnya nilai faktor K untuk beberapa tempat di Indonesia telah ditentukan oleh Pusat Penelitian Tanah, Bogor. Beberapa nilai K menurut jenis tanah dan bahan induk

\begin{tabular}{|c|c|c|c|}
\hline $\begin{array}{c}\text { Jenis klasifikasi } \\
\text { tanah }\end{array}$ & $\begin{array}{c}\text { Nilai } K \text { rata- } \\
\text { rata }\end{array}$ & $\begin{array}{c}\text { Jenis klasifikasi } \\
\text { tanah }\end{array}$ & $\frac{\text { Nilai } K \text { rata-rata }}{\text { (metrik) }}$ \\
\hline Latosol merah & 0,12 & Gley humic & 0,26 \\
\hline Latosol & 0,31 & Gley humic & 0,20 \\
\hline Regosol & $0,12-0,16$ & Lithosol & 0,16 \\
\hline Regosol & 0,29 & Lithosol & 0,29 \\
\hline Regosol & 0,31 & Grumosol & 0,21 \\
\hline Gley humic & 0,13 & Hydromorf abu-abu & 0,20 \\
\hline
\end{tabular}
penyusunnya dapat dilihat pada tabel 2 .

Tabel 1. Nilai M untuk beberapa klas tekstur tanah

\begin{tabular}{lclc}
\hline \multicolumn{1}{c}{ Kelas tekstur tanah } & Nilai M & Kelas tekstur tanah & Nilai M \\
\hline Lempung berat & 210 & Pasir geluhan & 1245 \\
Lempung sedang & 750 & Geluh berlempung & 3770 \\
Lempung pasiran & 1213 & Geluh pasiran & 4005 \\
Lempung ringan & 1685 & Geluh & 4390 \\
geluh lempung & 2160 & Geluh debuan & 6330 \\
Pasir lempung debuan & 2830 & Debu & 8245 \\
Geluh lempungan & 2830 & Campuran merata & 4000 \\
Pasir & 3035 & & \\
\hline
\end{tabular}

Sumber : RLKT DAS Citarum (1987) dalam Asdak (2004)

Tabel 2. Besarnya nilai K untuk jenis tanah di Indonesia

Sumber: Asdak (2004), Hidrologi dan Pengelolaan Daerah Aliran Sungai, hal. 365.

3) Faktor panjang lereng (L) dan kemiringan lereng (S)

Faktor indeks topografi $\mathrm{L}$ dan $\mathrm{S}$, masing-masing mewakili pengaruh panjang dan kemiringan lereng terhadap besarnya erosi. Panjang lereng mengacu pada aliran air permukaan, yaitu lokasi berlangsungnya erosi dan kemungkinan terjadinya deposisi sedimen.

Untuk menentukan panjang lereng digunakan persamaan Laflen and Moldenhauer (2003) dalam Asdak (2004):

$$
\mathrm{L}=(\lambda)^{\mathrm{m}}
$$


dimana:

$\mathrm{L} \quad=$ Faktor panjang lereng

$\lambda \quad=$ Panjang lereng $(\mathrm{m})$

$\mathrm{m}=$ Eksponensial dari panjang lereng yang berkisar antara 0,2-0,6. Di Indonesia yang sering digunakan adalah nilai 0,5 .

Untuk menentukan faktor kemiringan lereng digunakan persamaan (Arsyad, 2006):

$$
\mathrm{S}=\left(0,0138+0: 00965 \theta+0,00138 \theta^{2}\right)
$$

dimana:

$\mathrm{S}=$ Faktor kemiringan lereng

$\theta=$ Kemringan lereng (\%).

Dalam kenyataannya, panjang dan kemiringan lereng ( $L$ dan S) diintegrasikan menjadi faktor LS, dihitung dengan rumus:

$$
\mathrm{LS}=\sqrt{\frac{L}{22.13}\left(0.065+0.0453 S+0.0065 S^{2}\right.}
$$

dimana:

$\mathrm{L}=$ Panjang lereng $(\mathrm{m})$

$\mathrm{S}=$ Kemiringan lereng $(\%)$

Sedangkan Moore and Burch (1986) dalam Arsyad (2006), telah mengembangkan suatu persamaan untuk menentukan nilai LS dengan memanfaatkan data DEM pada SIG.

$$
\mathrm{LS}=(\mathrm{X} \times \mathrm{CZ} / 22,13)^{0,4} \times(\sin \theta / 0,0896)^{1,3}
$$

dimana:

$$
\begin{aligned}
& \mathrm{LS}=\text { Faktor panjang kemiringan lereng } \\
& \mathrm{X}=\text { Akumulasi aliran } \\
& \mathrm{CZ}=\text { Ukuran pixel } \\
& \theta \quad=\text { Kemiringan lereng }(\%)
\end{aligned}
$$

Akumulasi aliran merupakan nilai pixel yang dipengaruhi oleh aliran dari pixel dilereng atas. Pengolahan data DEM untuk mendapatkan nilai LS didalam penelitian ini menggunakan perangkat lunak ArcGis.

4) Faktor pengelolaan tanaman (C) dan tindakan konservasi tanah (P)

Faktor $\mathrm{C}$ menunjukkan keseluruhan pengaruh dari vegetasi, seresah, kondisi permukaan tanah, dan pengelolaan lahan terhadap erosi. Besarnya angka $\mathrm{C}$ tidak selalu sama dalam kurun waktu satu tahun, sehingga faktor $\mathrm{C}$ dalam persamaan USLE merupakan faktor independen.

Faktor $\mathrm{C}$ dalam persamaan erosi dimaksudkan untuk menunjukkan pengaruh vegetasi, seresah, permukaan tanah dan aktifitas pengolahan lahan terhadap terjadinya erosi.

Sedangkan pengaruh kegiatan pengelolaan dan konservasi tanah $(\mathrm{P})$ terhadap besarnya erosi dianggap berbeda dari pengaruh yang ditimbulkan oleh kegiatan pengelolaan tanaman (C). Faktor $\mathrm{P}$ adalah rasio perbandingan antara tanah tererosi rata-rata dari lahan yang mendapat perlakuan konservasi tertentu terhadap tanah tererosi rata-rata dari lahan yang diolah tanpa tindakan konservasi, dengan catatan faktor-faktor penyebab erosi yang lain diasumsikan tidak berubah. Di ladang pertanian, besarnya faktor P menunjukkan jenis aktifitas pegolahan tanah, sedangkan dalam bidang konstruksi, besarnya $\mathrm{P}$ menunjukkan kekasaran permukaan tanah akibat cara kerja mesin-mesin konstruksi.

Untuk daerah yang belum tersedia nilai $P$, dapat digunakan petunjuk umum untuk memperkirakan nilai tersebut dengan memanfaatkan tabel 3. Tabel tersebut menunjukkan beberapa nilai $\mathrm{P}$ menurut keadaan kemiringan lereng dan bentuk usaha konservasi tanah yang diterapkan. 
Tabel 3. Nilai faktor $\mathrm{P}$ menurut kontur dan terasering

\begin{tabular}{ccccc}
\hline Kemiringan & \multicolumn{3}{c}{ Nilai $P$} \\
\cline { 2 - 5 } lereng & Kontur & Tanaman Jalur & \multicolumn{2}{c}{ Teras } \\
\cline { 3 - 5 }$\%$ & & dlm Kontur & a) & b) \\
\hline $2-7$ & 0,50 & 0,25 & 0,50 & 0,10 \\
$8-12$ & 0,60 & 0,30 & 0,60 & 0,12 \\
$13-18$ & 0,80 & 0,40 & 0,80 & 0,16 \\
$19-24$ & 0,90 & 0,45 & 0,90 & 0,18 \\
\hline
\end{tabular}

Sumber: Soil Conservation Service (1972) dalam Asdak (2004)

dimana:

a) Erosi untuk pertanian

b) Erosi yang mengakibatkan sedimentasi di daerah hilir

Faktor $\mathrm{P}$ lebih mudah digunakan bila digabungkan dengan faktor $\mathrm{C}$, karena dalam kenyataannya kedua faktor tersebut berkaitan erat. Beberapa nilai faktor CP dapat ditentukan berdasarkan hasil penelitian yang telah dilakukan seperti pada tabel 4.

Tabel 4. Nilai faktor CP berbagai jenis penggunaan lahan

\begin{tabular}{lc}
\hline \multicolumn{1}{c}{ Konservasi dan Pengelolaan Tanaman } & Nilai CP \\
\hline Hutan: & 0.01 \\
a. tak terganggu & 0.05 \\
b. tanpa tumbuhan bawah, disertai seresah & 0.50
\end{tabular}

Semak:
a. tak terganggu
0.01
b. sebagian berumput
0.10

Kebun:

$\begin{array}{ll}\text { a. kebun-talun } & 0.02\end{array}$

b. kebun-pekarangan $\quad 0.20$

Perkebunan:

a. penutupan tanah sempurna $\quad 0.01$

a. penutupan tanah sebagian 0.07

Perumputan:
a. penutupan tanah sempurna
0.01
b. penutupan tanah sebagian; ditumbuhi alang-alang 0.02
c. alang-alang: pembakaran sekali setahun 0.06
d. serai wangi
0.65

Tanaman Pertanian:
a. umbi-umbian
0.51
b. biji-bijian
0.51
c. kacang-kacanga
0.36
d. campuran
0.43
e. padi irigasi
0.02

Perladangan:

a. 1 tahun tanam- 1 tahun bero $\quad 0.28$

b, 1 tahun tanam-2 tahun bero $\quad 0.19$

Pertanian dengan konservasi:
a. mulsa
0.14
b. teras bangku
0.04
c. contour cropping
0.14

Sumber: Asdak (2004), Hidrologi dan Pengelolaan Daerah Aliran Sungai, hal. 376. 


\section{b. Data debit}

Perkiraan erosi dengan memanfaatkan data debit, muatan sedimen, berat jenis tanah didaerah kajian. Pengumpulan data debit dan muatan sedimen dititik pengamatan (outlet) suatu DAS diusahakan dalam periode waktu yang cukup panjang (tahunan). Data muatan sedimen dalam jangka panjang diperoleh dari persamaan hubungan debit-sedimen (sediment discharge rating curve) dari data debit dan muatan sedimen yang tersedia dilokasi pengamatan. Dengan persamaan tersebut, maka data muatan sedimen untuk tahun-tahun berikutnya dapat dihitung hanya dengan menggunakan data debit.

\section{Evaluasi dan pengukuran erosi}

Evaluasi erosi merupakan penilaian mengenai kemungkinan besarnya erosi yang akan terjadi pada suatu wilayah. Penilaian atas kemungkinan besarnya erosi yang akan terjadi disebut erosi potensi atau penilaian terhadap ancaman tingkat bahaya erosi. Sedangkan evaluasi terhadap besarnya atau tingkat erosi yang telah terjadi pada suatu wilayah disebut pengukuran erosi total. Evaluasi erosi bertujuan untuk mengetahui bagian mana suatu lahan atau daerah yang mempunyai potensi untuk mengalami erosi dan kemungkinan ancaman erosi yang akan terjadi.

Evaluasi erosi terdiri dari tiga tingkatan pengamatan, yakni:

a. Tingkat Makro

Evaluasi erosi tingkat makro merupakan evaluasi umum suatu wilayah yang luas, meliputi satu pulau atau wilayah nasional, dilakukan dengan menggunakan peta skala 1:1.000.000 atau lebih kecil. Evaluasi erosi tingkat makro lebih dominan didasarkan pada analisis faktor iklim. b. Tingkat sedang

Evaluasi erosi tingkat sedang merupakan evaluasi erosi potensi yang meliputi luas wilayah yang lebih kecil seperti pada suatu DAS, Sub Das, wilayah kabupaten atau kecamatan dengan menggunakan peta dasar skala 1:20.000 sampai 1:500.000. Faktor-faktor yang dianalisis meliputi iklim, topografi, dan kondisi tanah.

c. Tingkat mikro

Evaluasi erosi tingkat mikro merupakan evaluasi erosi potensial yang meliputi suatu wilayah yang lebih sempit seperti suatu bidang tanah.

Selanjutnya evaluasi tingkat erosi dapat dinyatakan dalam indeks bahaya erosi yang didefenisikan oleh Hammer (1981) dalam Arsyad (2006):

Indeks Bahaya Erosi $=\frac{\text { Erosi Potensial (ton/ha/thn) }}{\mathrm{T} \text { (ton/ha/thn) }}$

dimana, T adalah besarnya erosi yang masih dapat ditoleransi.

Klasifikasi nilai indeks tingkat bahaya erosi menurut Hammer (1981) dalam Arsyad (2006) dapat dilihat pada tabel 5 .

Tabel 5. Klasifikasi indeks bahaya erosi

\begin{tabular}{ccc}
\hline No & $\begin{array}{c}\text { Nilai Indeks Bahaya Erosi } \\
(\text { Ton/Ha/Tahun })\end{array}$ & Kriteria \\
\hline 1 & $<1,00$ & Rendah \\
2 & $1,01-4,00$ & Sedang \\
3 & $4,01-10,00$ & Tinggi \\
4 & $>10,01$ & Sangat Tinggi \\
\hline
\end{tabular}

Sumber: Hammer (1981) dalam Arsyad (2006)

Nilai toleransi (T) didasarkan pada kriteria yang digunakan oleh Thompson (1957) dalam Arsyad (2006). Metode pendekatan yang digunakan dalam menentukan nilai T maksimum suatu tanah, yakni kedalam tanah dengan lapisan bawah yang permeabel diatas bahan yang telah melapuk sebesar $2,5 \mathrm{~mm} /$ tahun. Penentuan nilai $\mathrm{T}$ untuk tanah-tanah didalam suatu daerah aliran sungai telah mempertimbangkan ancaman pengendapan sedimen pada sungai 
atau badan-badan air, dan pada bangunan-bangunan infrastruktur sumber daya air lainnya. Besarnya nilai T untuk setiap kedalaman tanah di Indonesia dapat dilihat pada tabel 6.

Tabel 6. Besaran nilai T setiap kedalaman tanah

\begin{tabular}{|c|c|c|}
\hline No & Sifat tanah dan Substratum & $\begin{array}{c}\text { Nilai T } \\
(\mathrm{mm} / \text { tahun } \\
)^{2}\end{array}$ \\
\hline 1 & Tanah sangat dangkal di atas & 0,0 \\
\hline 2 & $\begin{array}{l}\text { Tanah sangat dangkal diatas tanah bahan yang telah } \\
\text { melapuk (tidak terkonsolidasi) }\end{array}$ & 0,4 \\
\hline 3 & Tanah dangkal diatas bahan telah melapuk & 0,8 \\
\hline 4 & Tanah dengan kedalam sedang diatas bahan telah & 1,2 \\
\hline 5 & melapuk & 1.4 \\
\hline 6 & Tanah yang dalam dengan lapisan bawah yang kedap air & 1,6 \\
\hline 7 & $\begin{array}{l}\text { Tanah yang dalam dengan lapisan bawah } \\
\text { berpermeabilitas lambat, diatas substrata yang telah } \\
\text { melapuk }\end{array}$ & 2,0 \\
\hline 8 & $\begin{array}{l}\text { Tanah yang dalam dengan lapisan bawahnya } \\
\text { berpermeabilitas sedang, diatas substrata telah melapuk } \\
\text { Tanah yang dalam dengan lapisan bawah yang } \\
\text { permeabel, diatas substrata telah melapuk }\end{array}$ & 2,5 \\
\hline
\end{tabular}

Sumber: Arsyad (2006), Konservasi Tanah dan Air, hal. 304.

Pengukuran besarnya tingkat erosi yang telah terjadi dilakukan menggunakan persamaan USLE. Dengan menggunakan hasil prediksi erosi yang merupakan besarnya ancaman erosi yang dihasilkan oleh erosi potensi pada setiap penggunaan lahan, selanjutnya dapat dihitung besarnya erosi total yang telah terjadi. Erosi total merupakan akumulasi besarnya erosi potensi dikalikan dengan luas unit masing-masing lahan.

Selanjutnya hasil evaluasi ancamam erosi dan pengukuran erosi dapat dipetakan. Peta erosi dapat berupa peta ancaman erosi dan peta erosi yang telah terjadi. Peta ancaman erosi menujukkan penyebaran tingkat ancaman atau besarnya erosi yang akan terjadi, termasuk bahaya tanah longsor pada suatu wilayah. Sedangkan peta erosi yang telah terjadi menunjukkan penyebaran besarnya erosi yang telah terjadi pada suatu wilayah.

Peta ancaman erosi berguna untuk perencanaan penggunaan lahan, sedangkan peta erosi yang telah terjadi berguna untuk perencanaan penanggulangan erosi, misalnya: pembuatan bangunan-bangunan pencegah erosi atau reklamasi tanah-tanah yang telah mengalami erosi.

Disamping menggunakan persamaan USLE untuk mengukur besarnya tingkat erosi yang telah terjadi. Beberapa metode untuk mengukur besarnya erosi yang telah terjadi oleh aliran permukaan, diantaranya:
a. Metode kotak penampung tanah tererosi
b. Metode petak percobaan di lapangan
c. Pengkuran kandungan sedimen sungai pada suatu DAS
d. Survei bathymetri pada waduk (reservoir)

\section{Metode konservasi tanah dan air}

Tindakan konservasi tanah adalah bagaimana menjaga agar kelestarian tanah tidak terdispersi, dan bagaimana mengatur kekuatan gerak dan jumlah aliran permukaan agar tidak terjadi pengangkutan tanah (erosi). Berdasarkan hal tersebut, maka ada tiga hal yang dapat dilakukan untuk tindakan konservasi tanah, meliputi:

a) Menutup tanah dengan tumbuhan dan tanaman atau sisa-sisa tumbuhan agar terlindung dari daya rusak butir-butir hujan yang jatuh 
b) Memperbaiki dan menjaga keadaan tanah agar resisten terhadap daya hancur agregat oleh tumbukan butir-butir hujan dan pengangkutan oleh aliran permukaan, memperbesar daya serapnya untuk menyerap air di permukaan tanah

c) Mengatur aliran permukaan agar mengalir dengan kecepatan yang tidak merusak dan memperbesar jumlah air yang terinfiltrasi ke dalam tanah.

Beberapa metode konservasi tanah dan air yang dapat dilakukan:

1) Metode vegetatif

Cara vegetatif adalah penggunaan tanaman dan tumbuhan, atau bagian-bagian tumbuhan untuk mengurangi daya tumbuk butir-butir hujan yang jatuh, mengurangi jumlah dan kecepatan aliran permukaan. Tindakan konservasi dengan cara vegetasi berfungsi untuk:

a) Melindungi tanah terhadap daya rusak butir-butir hujan yang jatuh

b) Melindungi tanah terhadap daya rusak air yang mengalir dipermukaan tanah

c) Memperbaiki kapasitas infiltrasi tanah dan penahanan air yang langsung mempengaruhi besarnya aliran permukaan.

Sedangkan penggunaan cara vegetasi dalam teknik konservasi tanah, meliputi: penanaman dalam strip, penggunaan sisa-sisa tanaman dan tumbuhan, penggunaan bahan geotekstil, strip penyangga riparian, tanaman penutup tanah, pergiliran tanaman, serta penghutanan kembali.

2) Cara Mekanis

Tindakan konservasi secara mekanis adalah bagaimana memperlakukan tanah secara fisik dengan menahan, menampung, dan mengendalikan tanah yang tererosi menggunakan bangunan-bangunan penahan tanah. Hal ini dimaksudkan untuk mengurangi aliran permukaan dan erosi, dan meningkatkan kemampuan penggunaan tanah.

Konservasi tanah secara mekanis berfungsi untuk:

a) Memperlambat aliran permukaan

b) Menampung dan menyalurkan aliran permukaan dengan kekuatan yang tidak merusak

c) Memperbaiki atau memperbesar infiltrasi air kedalam tanah dan memperbaiki aerasi tanah

d) Sebagai sumber air bagi tanaman.

Beberapa alasan untuk menerapkan konservasi tanah secara mekanis, yakni:

1) Aliran debris yang berasal dari daerah hulu akan mengancam bangunan-bangunan penting yang ada di daerah hilir.

2) Reklamasi di daerah hulu dianggap penting bagi kehidupan masyarakat didaerah tersebut.

3) Hasil produksi sumber daya alam seperti hasil pertanian, hutan, dan air di daerah tersebut lebih besar daripada biaya yang akan dikeluarkan untuk pembuatan bangunan pencegah erosi.

Sedangkan tujuan utama pembuatan bangunan pencegah erosi yang merupakan usaha konservasi secara mekanis adalah untuk mengurangi kecepatan dan volume air larian serta kehilangan tanah dengan cara menahan air tetap pada tempatnya atau minimal mengurangi kecepatan air lariannya, sampai saatnya vegetasi yang ditanam ditempat tersebut cukup kuat untuk meneruskan pertumbuhannya. Bentuk bangunan pencegah erosi yang umum dijumpai adalah terasering, bangunan terjunan, pengendali jurang, saluran pembuangan, serta dam penahan.

3) Metode kimia

Metode kimia dalam konservasi tanah dan air adalah penggunaan bahan-bahan kimia berupa senyawa sintetik maupun berupa bahan alami yang telah diolah dalam jumlah yang relatif sedikit, untuk meningkatkan stabilitas agregat tanah dan mencegah terjadinya erosi.

Struktur tanah yang stabil merupakan salah satu faktor yang berpengaruh positif terhadap pengurangan kepekaan erosi tanah dan pertumbuhan tanaman. Bahan organik tanah sangat berperan dalam pembentukan struktur tanah yang stabil dan juga sebagai reservoir unsur 
hara, memperbaiki struktur tanah, drainase tanah, peredaran udara tanah (aerasi), kapasitas tukar kation tanah, kapasitas penyangga tanah, kapasitas penahan air tanah, dan merupakan sumber energi bagi mikro-organisme.

Biasanya tanah setelah diolah dan dibersihkan dari vegetasi penutupnya, maka bahan organik tanah akan cepat sekali menurun, sehingga kepekaan tanah terhadap erosi akan cepat meningkat dan produktifitas tanah dengan cepat dapat menurun. Untuk meningkatkan kembali bahan organik dalam kandungan tanah, diperlukan preparat-preparat kimia organik sintetik untuk membentuk kembali struktur tanah yang stabil (Arsyad, 2006)

4) Kombinasi cara vegetasi dan mekanis

Teknik pencegahan erosi yang paling efektif adalah kombinasi dari cara vegetatif dan cara mekanis. Cara vegetatif menekankan kegiatan pencegahan erosi dengan cara penanaman vegetasi. Sedangkan dengan cara mekanis melalui pembuatan bangunan pencegah erosi.

Untuk mengembalikan kualitas lahan yang telah tererosi, diperlukan rehabilitasi lahan dan konservasi tanah, dengan cara:

a) Menambah stabilitas dan ketahanan permukaan tanah terhadap erosi dan mengurangi gerakan massa tanah

b) Mengurangi kekuatan aliran erosi dengan cara mengurangi kecepatan aliran dan debit.

c) Memperbesar kapasitas infiltrasi suatu lahan dan menambah kapasitas daya resapnya.

Tindakan-tindakan untuk mengembalikan kualitas lahan suatu DAS/sub das, dapat dilakukan dengan cara bio engineering, yakni tindakan jangka panjang berupa penanaman tumbuhan penutup sehingga diperolah kerapatan tutupan lahan, sehingga dapat mencegah denudansi, dan mengatur tata guna lahan. Beberapa dampak dengan adanya tumbuhan penutup lahan, yakni:

1) Mengurangi daya rusak jatuhnya titik-titik air hujan pada permukaan tanah karena telah dikurangi oleh tajuk pepohonan.

2) Lapisan permukaan tanah yang terbentuk akibat reruntuhan daunan, ranting-ranting yang telah membusuk, serta tonjolan akar dan batang-batang pohon, akan menghambat laju limpasan permukaan, serta mengurangi kecepatan aliran air sehingga mengurangi daya erosinya

3) Perakaran yang menembus tanah akan menambah kapasitas infiltrasi air dan menyerap debit aliran permukaan dengan cepat.

4) Pepohonan yang berakar tunjang pada kaki lereng akan menambah stabilitas kekuatan lereng dan menghalangi terbentuknya erosi parit. Akar-akar pohon juga akan menambah porositas lereng sehingga memungkinkan terserapnya air tanah secara bekesinambungan, serta mencegah kejenuhan lereng oleh air dengan cara memperkecil tekanan pori pemicu terjadinya longsoran lereng.

\section{B. Sedimen}

Sedimen merupakan hasil proses terjadinya erosi, baik akibat erosi permukaan, erosi parit, dan longsoran tebing. Laju sedimen adalah banyaknya tanah dan bagian-bagian tanah yang terangkut oleh air dari suatu tempat yang mengalami erosi pada suatu daerah aliran sungai dan masuk kedalam sungai atau badan-badan air (Arsyad, 2006). Sedimen yang terbawa masuk kedalam sungai hanya sebagian saja dari tanah yang tererosi dari tempatnya, sebagian lagi dari tanah yang tererosi tersebut akan mengendap pada suatu tempat dibagian bawah tempat erosi terjadi. Sedimen umumnya mengendap pada tempat-tempat di bawah kaki bukit, di daerah genangan banjir, di dalam saluran air, sungai, dan waduk.

Sedimen yang dihasilkan oleh proses erosi dan terbawa oleh aliran air akan diendapkan pada suatu tempat yang kecepatan aliran airnya melambat atau terhenti. Peristiwa pengendapan ini merupakan proses sedimentasi yang membentuk dataran-dataran alluvial yang luas dan banyak terdapat dibelahan bumi ini. Akibat sedimentasi yang mengendap di dalam saluran 
air, sungai, waduk dan hilir sungai, maka akan menyebabkan pendangkalan badan-badan air, serta akan menimbulkan masalah karena mengurangi fungsi badan air.

\section{Sediment delivery ratio (SDR)}

SDR (Sediment Delivery Ratio) merupakan rasio perbandingan jumlah sedimen yang terangkut masuk ke dalam badan air/sungai dengan jumlah erosi yang terjadi di hulu DAS. Apabila nilai SDR mendekati satu, artinya semua tanah yang terangkut erosi masuk kedalam sungai, sebaliknya bila nilai SDR mendekati nol, maka laju erosi pada DAS tersebut sangat kecil dan menunjukkan bahwa DAS tersebut dalam kategori baik.

Cara memperkirakan besarnya hasil sedimen dengan menghitung nilai SDR suatu daerah tangkapan air ditentukan berdasarkan hasil analisis tingkat erosi. Cara ini menjadi umum digunakan apabila pada suatu DAS tidak memungkinkan untuk dilakukan pengukuran sedimen secara langsung dilapangan.

Untuk menghitung besarnya koefisien SDR pada tiap-tiap sub das didasarkan pada persamaan empiris yang dikembangkan oleh Auerswald (1992) dalam Arsyad (2006):

$$
\mathrm{SDR}=-0,02+0,385 \mathrm{~A}^{-0,2}
$$

dimana:

$$
\begin{array}{ll}
\text { SDR } & =\text { Nisbah pelepasan sedimen } \\
\mathrm{A} & =\text { Luas Sub DAS }
\end{array}
$$

Besarnya hasil sedimen ditentukan berdasarkan rumus DPMA (1984) dalam Asdak (2004):

$$
\mathrm{Y}=\mathrm{E}(\mathrm{SDR}) \mathrm{W}_{\mathrm{s}}
$$

dimana:

$$
\begin{aligned}
& \mathrm{Y}=\text { Besarnya laju sedimen } \\
& \mathrm{E}=\text { Erosi total } \\
& \mathrm{SDR}=\text { Sediment delivery ratio } \\
& \mathrm{W}_{\mathrm{s}}=\text { Luas daerah tangkapan air }
\end{aligned}
$$

Besarnya SDR juga dapat ditentukan berdasarkan grafik hubungan antara luas DAS dan besarnya SDR sebagaimana yang dikemukakan oleh Roehl (1962) dalam Asdak (2004) seperti pada gambar 2. Grafik hubungan luas Sub Das dan nilai SDR tersebut dikembangkan berdasarkan hasil penelitian yang telah dilakukan dalam kurun waktu yang sangat panjang dan melibatkan sejumlah karakteristik DAS diseluruh dunia.

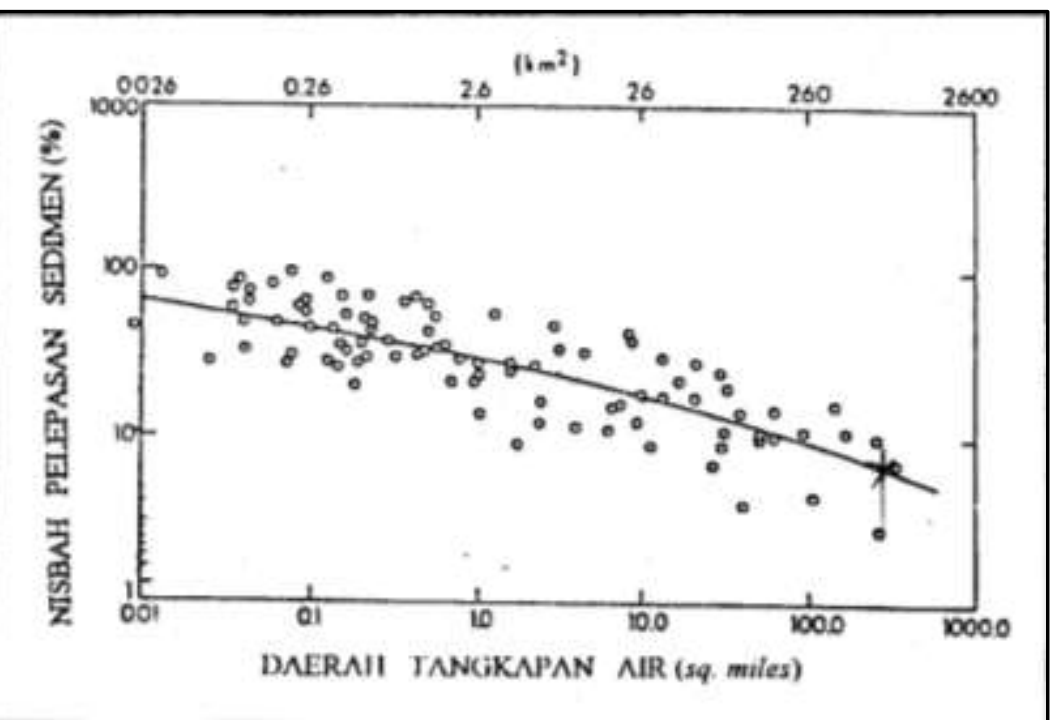

Gambar 1. Besarnya angka SDR berdasarkan luas DAS 


\section{Sedimen dan angkutan sedimen}

Jenis sedimen tergantung pada ukuran partikel-partikel tanah serta komposisi mineral dari bahan induk yang menyusunnya. Beberapa material yang dapat menjelma menjadi sedimen, diantaranya: pasir dan tanah liat. Jenis sedimen menurut ukuran partikelnya dapat ditemukan terlarut dalam sungai atau yang disebut dengan muatan sedimen (suspended load) dan sedimen yang merayap di dasar sungai disebut sedimen merayap (bed load). Karakteristik sedimen ditentukan berdasarkan ukuran butiran sedimen, sebagaimana pada tabel 7:

Tabel 7. Klasifikasi ukuran butiran sedimen

\begin{tabular}{ll}
\hline \multicolumn{1}{c}{ Jenis sedimen } & \multicolumn{1}{c}{ Ukuran partikel (mm) } \\
\hline Liat & $<0,0039$ \\
Debu & $0,0039-0,0625$ \\
Pasir & $0,0625-2,0$ \\
Pasir besar & $2,0-64,0$ \\
\hline umber: Dunne dan Leopold (1978) dalam Asdak (2004).
\end{tabular}

Sedangkan perbedaan antara muatan sedimen dan sedimen merayap terletak pada cara partikel-partikel sedimen tersebut bergerak yang ditentukan oleh besar kecilnya ukuran partikel. Muatan sedimen yang berukuran kecil adalah gerakan partikel-partikel tanah yang dapat terlarut dalam air, sedangkan ukuran partikel yang lebih besar tidak dapat larut dalam air melainkan mengendap diatas permukaan tanah untuk kemudian bergerak merayap apabila mendapat dorongan dari luar.

Kecepatan angkutan sedimen merupakan perkalian antara berat partikel sedimen dengan kecepatan rata-rata partikel sedimen tersebut. Sedangkan kecepatan gerak suatu benda adalah jarak dibagi lama waktu benda tersebut bergerak. Sementara daya suatu benda adalah besarnya energi suatu benda yang diperlukan untuk bergerak dari satu titik ke titik lainnya. Kekuatan atau daya untuk menggerakkan suatu benda adalah (berat x jarak) / waktu. Dalam memperhitungkan kecepatan laju sedimen, maka besarnya koefisien gesekan juga harus diperhitungkan.

Besarnya angkutan sedimen dalam aliran air sungai merupakan fungsi dari suplai sedimen dan energi aliran sungai. Ketika besarnya energi aliran sungai melebihi kapasitas suplai sedimen oleh sungai maka terjadilah degradasi sungai. Sebaliknya bila suplai sedimen lebih besar daripada energi aliran sungai, maka terjadilah agradasi sungai.

Kecepatan angkutan sedimen merupakan fungsi dari kecepatan aliran sungai dan ukuran partikel sedimen. Ukuran partikel yang lebih kecil dapat terangkut dalam air dalam bentuk terlarut (wash load), sedangkan partikel yang berukuran agak lebih besar, mekanisme angkutan sedimennya cenderung akan melompat. Kedua jenis ukuran partikel sedimen tersebut termasuk dalam sedimen melayang (suspended load). Partikel yang berukuran besar, mekanisme angkutan sedimennya akan menggelinding didasar sungai (bed load)

Besarnya ukuran sedimen yang terangkut didalam air ditentukan oleh interaksi ukuran sedimen yang masuk ke badan air, karakteristik saluran, debit, dan karakteristik fisik partikel sedimen. Laju sedimen yang masuk ke dalam sungai dan besarnya debit ditentukan oleh faktor iklim, topografi, geologi, vegetasi dan cara pengelolaan lahan di daerah tangkapan air yang merupakan asal datangnya sedimen. Sedangkan karakteristik sungai ditentukan oleh bentuk morfologi sungai, tingkat kekasaran dasar sungai, dan kemiringan sungai. Hubungan dan interaksi dari masing-masing faktor tersebut akan menentukan jumlah dan tipe sedimen, serta kecepatan angkut sedimen.

\section{Hasil sedimen}

Hasil sedimen tergantung pada besarnya erosi total yang terjadi pada suatu DAS atau Sub DAS dan tergantung pada angkutan partikel-partikel tanah yang tererosi. Produksi sedimen mengacu pada besarnya laju sedimen yang mengalir melewati satu titik pengamatan dalam 
suatu DAS/Sub DAS. Besarnya hasil sedimen tergantung karakteristik fisik suatu DAS/Sub DAS dan dinyatakan sebagai volume atau berat sedimen per satuan luas daerah tangkapan air per satuan waktu.

Pengukuran besarnya sedimen yang paling memadai adalah melalui pengukuran sedimen yang dilakukan di dasar waduk. Cara lain yang dapat digunakan adalah dengan pembuatan kurva debit sedimen (sediment-debit rating curve), yakni kurva yang menghubungkan laju angkutan sedimen dengan besarnya debit.

\section{Pembahasan Khusus : Aliran Sedimen dalam Pipa}

Ada beberapa pembagian regime aliran sedimen dalam pipa atau juga dikenal sebagai perilaku aliran slurry, antara lain adalah (Pristianto, 2018) :

1. Terdapat 3 model transpor sedimen dalam pipa, yaitu:

- Pesudohogeneous suspension - terjadi pada sedimen halus dan kecepatan aliran tinggi. Kriteria untuk pembentukan suspensi secara penuh adalah kecepatan rerata aliranya 200 kali kecepatan jatuhnya partikel dan diameter butiran sedimen $<150$ $\mu \mathrm{m}$.

- Heterogeneous suspension - untuk kecepatan lebih kecil dan material lebih kasar dari kriteria sebelumnya, dan terbentuk dengan distribusi konsentrasi aliran sedimen yang sangat tidak seragam. (diameter butiran sedimen lebih besar dari $150 \mu \mathrm{m}$ dan kurang dari $1 \mathrm{~mm}$ ).

- $\quad$ Sliding Bed Regime - untuk material yang sangat kasar dan seluruh material sedimen akan ditranspor meluncur sepanjang dinding pipa. Untuk memulai suspensi, tipe ini membutuhkan kecepatan rerata aliran sebesar 30 kali kecepatan jatuh partikel, atau kecepatan jatuh partikelnya sebesar $10 \mathrm{~cm} / \mathrm{dt}$ dan diameter butiran sedimen lebih besar dari $1 \mathrm{~mm}$.

2. Terdapat empat regime aliran sedimen dalam pipa, yaitu :

- Homogeneous Flow - Dalam aliran homogen, partikel zat padat tidaklah terdistribusi secara seragam melintasi cross section saluran pipa, tetapi ditemukan dalam aliran slurry yang konsentrasinya tinggi dan pada ukuran partikel halus. Aliran Slurry yang memperlihatkan sifat aliran homogen tidak cenderung untuk diam, tapi membentuk suatu endapan dalam kondisi mengalir. Contoh tipe homogeneous slurries adalah lumpur buangan, lumpur pengeboran, bubur kertas, batu gamping halus dan lain-lain.

- Aliran Heterogen (Heterogeneous Flow) - Dalam kondisi aliran heterogen, terdapat suatu penyebutan gradien konsentrasi yang melewati cross section saluran pipa. Aliran slurry pada konsentrasi yang rendah dengan secara cepat mengendapkan partikel kasar adalah memperlihatkan sifat aliran heterogen. Contoh khususnya adalah slurry pasir dan kerikil, slurry batubara kasar, dan slurry buangan tambang yang kasar.

- Regime Pertengahan (Intermediate Regime) - Tipe ini terjadi ketika bagian dari suatu partikel secara homogen terdistribusi pada saat yang lain juga terdistribusi secara heterogen. Aliran intermediate regime diharapkan pada pengangkutan slurry buangan tambang dari proses pabrik mineral dan pengangkutan slurry batubara-air.

- Saltation Regime - Aliran turbulen tidak mungkin cukup untuk menjaga pengendapan partikel dengan cepat pada suspension. Perjalanan partikel dengan lompatan atau mengguling yang terputus-putus sepanjang dasar yang meluncur atau dasar tetap pada bagian bawah pipa. Tipe aliran ini akan terjadi pada slurry kasar dan kerikil.

Hasil penelitian yang yang terkait adalah penelitian yang dilaksanakan di Laboratorium Hidrolika Fakultas Teknik Universitas Hasanuddin Makassar pada tahun 2010 , tentang 
sistem pengurasan untuk pembersihan pipa fluidisasi, dapat dihasilkan beberapa kesimpulan antara lainadalah klasifikasi regim aliran sedimen dalam pipa pada penelitian ini menyebutkan bahwa untuk tinggi sedimen $0,5 \mathrm{D}$ dan $0,75 \mathrm{D}$ didapati aliran sedimen dalam regim aliran intermediate, sedangkan apabila tinggi sedimen di dalam pipa adalah $0,9 \mathrm{D}$, maka regim alirannya adalah heterogen (Pristianto, 2010).

\section{DAFTAR PUSTAKA}

Arsyad, S., 2006. Konservasi Tanah dan Air. IPB Press, Bogor.

Asdak, C., 2004. Hidrologi dan Pengelolaan Daerah Aliran Sungai. Gadjah Mada University Press, Yogyakarta.

As-syakur, A.R., 2008b. Prediksi Erosi dengan Metode USLE dan SIG, (Online),

Pristianto, H. (2018, May 15). Teori Aliran Sedimen Dalam Pipa. http://doi.org/10.17605/OSF.IO/BFV7G

Pristianto, H. (2010, October 6). Sistem Pengurasan Untuk Pembersihan Pipa Fluidisasi. http://doi.org/10.17605/OSF.IO/TAQ8H 